\title{
The African Women Theologians' contribution towards the discussion about alternative masculinities
}

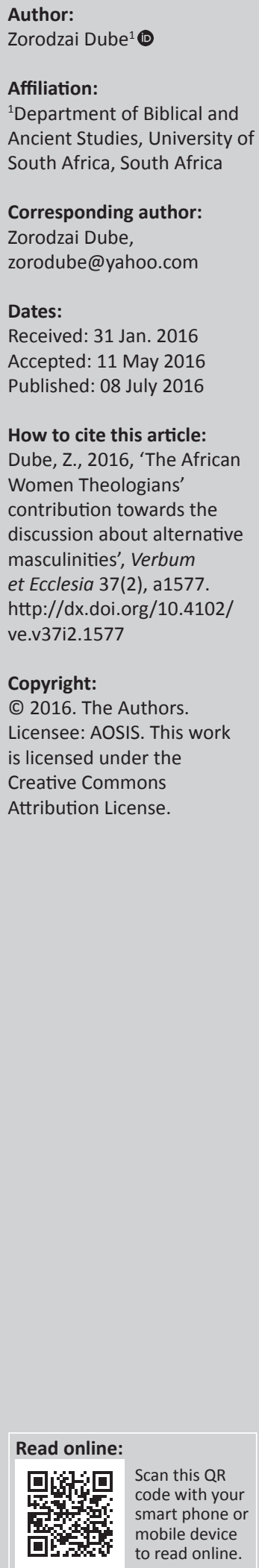

In a celebratory mood because of the unparalleled, heroine works of the Circle of Concerned African Female Theologians, from hereon the CIRCLE, I pose to assess their use of critical tools such as alternative masculinities. Largely, the CIRCLE writers engaged with the concept of alternative masculinity from the perspective of Christology, associating Jesus with 'motherlike' virtues of caring and loving, which also became the basis to critique African hegemonic masculinities and patriarchy. While success has been achieved from a cultural perspective, in this study I suggest that emphasis should be diverted towards exploring strategies that empower women economically.

Intradisciplinary and/or interdisciplinary implications: The study uses theories from cultural studies, critical theory, and contextual and gender studies to locate the voices of African women theologians in their discussion of Alternative masculinity. By using contextual Christologies based on the African woman's experience, the study adds to knowledge concerning the discussion of gender and alternative masculinities, in the process, highlighting the voices of African women theologians to the discussion.

\section{Introduction}

The CIRCLE theologians have done extraordinary work which is evidenced by the volume of their academic work. To the academy, through their work, they exposed the perceived inadequacies associated with the Western interpretive tool, especially, that the foreign tools are ideologically loaded and that they do not answer particular contextual questions. Through their various academic writings, CIRCLE theologians have provided alternative perspectives such as the womanhood (Oduyoye 2001), Bosadi (Masenya 2015) and Biblical Hermeneutics of Life (Okure 2000). These perspectives are unique because they derive from the real life issues affecting the African women. They reminded us that theology starts with the people's experiences, and not with textual criticism. In Western-influenced perspectives, theology was conceived as the privilege of a few, those with skills in textual analysis. Despite using different terms and semantics, the CIRCLE writers shared the theme that theology should affirm life and connect with the real experiences of African women.

This study, written at the occasion to celebrate the hard work done by the CIRCLE theologians, reviews the CIRCLE's use of alternative masculinities, a perspective that calls for alternative forms of manhood or masculinities. To emphasise, discussions around alternative masculinities does not call for biological change in men, but instead promote tolerance in accepting various forms of sexualities, deconstructing gender barriers and promoting economic equality. The CIRCLE writers, implicitly and explicitly, while engaging issues associated with patriarchy, wrestled and explored alternative forms of being a man. This study accomplishes the following three objectives:

- to define and explore the various global perspectives within the discussions about alternative masculinities

- to demonstrate how the CIRCLE writers engaged with alternative masculinities as a theory and praxis

- to offer critique and suggest avenues towards which the discussion concerning alternative masculinities can be redirected. In the last section, I offer my evaluation and suggests the possible alternative focus for the discussion.

\section{Perspectives within alternative masculinities}

Conceptually conceived as different from traditional pervasive hegemonic masculinities, alternative masculinities is a perspective known by different terms, for example, redemptive masculinities (Chitando 2004:151). Traditional forms of masculinities are accused of perpetuating 
gender-based violence, women and child abuse, and economic and political violence. It is perceived as being associated with historical evils such as wars, imperialism and colonialism (Halberstam 1998:2). Alternative masculinities house different perspectives depending on the issues. Three perspectives are noticeable, which are:

- a perspective that focuses on socialisations and culture as the cause of hegemonic masculinity

- a perspective that emphasises economic disparity between men and women or inequality in general

- a perspective concerned with sexuality, raising matters related to alternative sexualities.

The first category of voices uses alternative masculinities as a tool to criticise patriarchal culture. It comprises voices of feminist movements, pro-feminist movements, and gays and lesbians. They argue that, due to socialisation, men are wrongly socialised into believing that they are biologically conditioned to lead, control and decide for everyone. Kate Millet (1971:21) says patriarchy and masculinity permeate all spheres of life politics, military, technology and universities - to ensure the dominance of men. However, she acknowledges that masculinities are malleable, depending on context. Scholars with similar perspectives are R.W. Connell and Messerschmidt (2005:829), J. Hearn and Morgan (1990:5), M. Kaufman (1989:20), M. Kimmel (1989:4) and Robert Morrell (2007:16). A majority of voices within this category look into ways in which masculinities can be re-socialised. Much focus has been on young boys. The voice of Bob Pease (2014) captures the collective concern of this group, saying:

the challenge that confronts men is to find ways to exercise power without oppressing anyone. For men to change for the better, power must be redefined so that men feel powerful when doing things that are not traditional for men. (p. 17)

Marta Bosch Vilarrubias (2014:205) made conclusions from her study of the shifting gender roles among the Iranian migrants in the Americas.

The focus of this group is to attain collaborative and complementary forms of manhood that can function as important variables in tackling gender-based violence and domestic or workplace abuse. Within this group, alternative masculinity functions as a tool to critique the manner in which culture broods patriarchy and hegemonic masculinities. They call people to be free from any form of oppression; it is people's right to live as they please without cultural baggage. Most of their ideas have been deployed against certain oppressive practices within the African culture. For example, most African societies expect women to fetch water, firewood, cook and carry all domestic chores. In cases where lobola was fully paid, a woman is expected to be obedient. The African culture even condones beating wife, in cases where she is seen as not obedient to the husband.

The second category of voices used alternative masculinities to criticise economic disparity, arguing that inequality is a violation of people's rights to live with dignity (Carabi \& Armengol 2014:1). Perspectives under this category are influenced by Marxist views. Fedelma Ashe (2007:1) says that economic imbalance is the primary cause of gender-based violence and that the struggles of women are due to economic hegemony driven by capitalism. As remedy:

men should recognise their false unequal entitlement to power, they should contest the cultural values of dominance and develop an ethical responsibility to act out more equitable gender relations. (Carabi \& Armengol 2014:1)

They call for new masculinities that condemn capitalism in favour of a relational philanthropic approach to economics (Mutua 2006:3). Capitalism, as an economic framework, encourages unhealthy competition and gross inequality.

The third category of voices use alternative masculinities to contest the essentialisation of the social category 'man', arguing that sexuality, or specifically heterosexuality, should be contested. Traditional forms of masculinity look upon other forms of manhood as less human or less man, associating manhood with being macho or the ability to sire children (Flecha, Puigvert \& Ríos 2013:88). Can the category 'man' exist without associating it with sexuality? Implicitly, this category argues that sexuality props up hegemonic masculinities, and as an alternative, sexuality should not be used as base for gender categories. Therefore, alternative forms of sexuality should be encouraged. For example, David Leverenz (2014:63) researched about ageing men who have lost their testosterone, and concluded that they exhibit less aggressive forms of manhood, notably through caring, collaborative behaviour and understanding.

Despite different categories and emphasis, the common denominator is that alternative masculinities advocate for alternative forms of manhood that are less hegemonic and imperial. In contrast to traditional hegemonic manhood, which is associated with power and authority, it calls for a decentred manhood that collaborates, listens and builds communities and households. Among others, alternative masculinities exhibit themselves through being non-violent and a sensitive approach to politics and economy. With regard to sexuality, other sexual orientations should be tolerated. (Carabi \& Armengol 2014:1; Connell \& Messerschmidt 2005:829).

\section{Historical influences}

Before discussing how the CIRCLE writers engage with discussions about alternative masculinities, we need to understand the historical influences undergirding the discussions about alternative masculinities. Notably, two major historical influences can be singled out.

The first point could be seen as an indirect influence. The shift from being colonial entities to independent geographies created space for discussions about other liberations - gender, economic, education and others. However, I argue that political liberation should be regarded as an indirect and 
distant influence because, despite political independence, patriarchy and economic imperialism continued. However, importantly, we can describe the attainment of political independence, as the commencement of postmodern spaces where people could question structures and dogmas.

Secondly, the advert of postmodernism, a worldview that opposes meta-narratives and promotes individual freedom, coincided with the campaign for individual rights after the 1950s and gained momentum in the 1980s (Elliott 2007:343). The 1950s are significant in that, not only do we witness a world healing from the aftermath of World War II, but the universal campaign for other forms of freedom. The desire for universal human freedom should be understood within the matrix of postmodernity, which is a worldview and mindset that promotes individual freedom and choices. In this regard, institutions - family, church or state - should not be prescriptive, instead they should be engaging. A leading voice concerning this topic is Michael Elliott (2007:343). In an article, Human Rights and the Triumph of the Individual in World Culture, ${ }^{1}$ Michael Elliott (2007:343) explains that the discussions about universal rights are a process which is driven by a broader world culture where the individual is increasingly regarded as sacred and inviolable' (Elliott 2007:346). Rights are talked about in relation to private behaviours such as sex. The campaign for the poor and their need for resources such as water, sanitation and food were packaged as human rights. To live is a right. Due to the perversity of human rights, economic oppression and political oppression are condemned as infringing on the rights of individuals.

We live in a generation where 'rights' is a new worldview; there are no universally imposing structures in the forms of the church or state; people have the right to question the church's teaching and impositions from the state. It is within this discursive canopy that we locate the discussions about alternative masculinities. The next stage is to explore how, under the influence of freedom and rights, the CIRCLE approached the subject of alternative masculinities.

\section{The CIRCLE and alternative masculinities}

The CIRCLE writers seized the discussions about alternative masculinities to critique African patriarchal cultures that keep women oppressed. They appeal to their particular contexts, as African women, as starting point for developing theology and Christology. Central to this study is, how did the CIRCLE writers explore the issue of alternative masculinities? Most of the writings by the CIRCLE members approach the issues of alternative masculinities from the perspective of constructing alternative Christology. Generally, they accuse the academy and Western scholars for constructing patriarchal Christology. For example, Jesus is

\footnotetext{
1.Earlier campaigns and foundation to economic equality had already been made by luminary figures such as Karl Marx (1887:2) in the previous century. However, after luminary figures such as Karl Marx (1887:2) in the previous century. However, after
1945 , discussions about human rights were made in connection with almost 1945 , disc
anything.
}

described through men's gender - Jesus the exalted, the Lord and Messiah, all contain male cultural images. The same accusation applies to African patriarchal Christology which tagged Jesus with masculine gender titles - the king, the chief or prince. Teresa Okure (2000:194) argues that Christology did not fall from heaven; it is constructed from experience. They accuse Western Christology for being patriarchal, imperial and only speaking from the gendered position of men. Therefore, there is a need for Christology that resonates with the experiences of African women (Dube 2013:91, Stanton 1993:7).

A pioneering voice is Mercy Oduyoye (1988:32), the mother of African women's theology. She argues that, in view of African women's experiences of suffering, Jesus cannot be interpreted using Western patriarchal dogmas. Oduyoye's work spans over 40 years of academic research as lecturer in Nigeria and as coordinator at the World council of churches. In humility, I should say that my summary does not capture all, but it reflects the heartbeat of her discussion regarding the subject of alternative masculinities. For her, Jesus possesses mother-like qualities; Jesus suffer with the poor and oppressed. Jesus, like a mother, empathises by incarnating into the experiences of those who suffer to change their predicament through caring, loving and offering hope. In women's experiences:

Christ becomes truly friend and companion, liberating women from assumptions of patriarchal societies, and honouring, accepting, and sanctifying the single life as well as the married life, parenthood as well as the absence of progeny. The Christ of the women of Africa upholds not only motherhood, but all who, like Jesus of Nazareth, perform 'mothering' roles of bringing out the best in all around them. This is the Christ, high priest, advocate, and just judge in whose kingdom we pray to be. (Oduyoye 1988:32)

Writing from the contextual experiences of African women, Oduyoye (1988:32) deconstructs the patriarchal descriptions that associate Jesus with power, territoriality and kingdom. She sees Western Christology as imposing imperial patriarchal models on Jesus which do not address the needs of African women.

The mother-like Jesus is Oduyoye's (1988:32) attempt to describe alternative masculinities derived from African women's experiences. Deductively, the mother-like Jesus deconstructs patriarchy and calls for new images of manhood based on caring and loving. Patriarchy replicates itself through religious myths found within the African worldview and the Bible, building a canopy of conformity. Myths, according to Oduyoye (1988:32), alienate women from being an active agency. Unless women confront oppressive myths, they will continue to be oppressed. However, in dealing with oppressive myths, Oduyoye (1988:32) is comfortable with assigning new models of caring and loving to Jesus without questioning the gender of Jesus. Can Jesus be separated from his gender as a Jewish man, buoyed within an ancient patriarchal culture? Are the model of caring and loving connected to the historical Jesus? These questions go to the 
heart of how Oduyoye (1988:32) interprets the Bible. Oduyoye (1988:32), like Okure (2000:194), sees the Bible as a collection of experiences which, for the African woman, can be retold. Meaning is in resonance, that is how the hearers (in this case the Daughters of Anowa or African women) make sense of the stories. It seems for Oduyoye (1988:32), unlike his Jewish contemporaries, Jesus was pro-women and the poor.

Equally, Teresa Okure (2000:194), in agreement with Oduyoye (1988:32), coined the phrase Biblical Hermenuetics of Life to argue that the interpretation of the Bible should be towards the liberation of humanity from all forms of oppression. Plausibly, Okure (2000:194) broadened Oduyoye's motherlike metaphor to the notion of life. A mother is a source of life and there the task of theology is to promote life. Concerning our topic, therefore, alternative masculinities should promote life. For Okure (2000:194), the interpretation of the Bible is, simultaneously, a process of seeking to better the living conditions of people. Thus reading the Bible is to search for its liberative strands to life. Like Oduyoye, Okure (2000:194) starts with the experiences of the people, arguing that, in the beginning it was life with God and later came the Bible. This is not to denigrate the Bible but rather to take a hermeneutical lens of life to read across the Bible.

Furthermore, Oduyoye shares with Masenya (2015:78) the need to criticise the patriarchal imports associated with Jesus and the Bible. I draw from her recent publication which seems to crystallise her arguments and ideas. Masenya's (2015:78) common phrase is 'life affirming', which reminds us of Okure and Oduyoye. She coined the Bosadi (womanhood) approach to argue that a hermeneutic of suspicion is needed when reading the Bible. True, the Bible is life affirming, but it should not be taken at face value. Being South African and coming from the context where the Bible was subjectively used to support apartheid, Masenya (2015:78) is cautious in her approach to the Bible. Not everything within the pages of the Bible is life affirming, she insists. Instead while drawing the life-affirming narratives from the Bible, theologians should be careful not to blindly accept everything from the Bible as God's word. She says:

Issues concerning patriarchy, particularly in its multifaceted forms in differing women's contexts need to be treated as a matter of urgency in our Biblical interpretation endeavour. (Masenya 2015:78)

A majority of African women theologians voiced against the manner in which the African culture finds hideout in similar biblical patriarchal culture. For example, Musimbi Kanyoro (2002:17; also van Klinken 2013:30), taking a constructivist approach to gender, argues that the Bible comes from a patriarchal culture and thus exegetes should be aware of the cultural imports that oppress women. There is need to be critical of the culture behind and reflected in the Bible. Equal caution is needed regarding our own culture. Equally, Isabel Phiri (2007:155) says reading of the Bible that empowers women should begin by identifying the contextual challenges that oppress women-child marriage, exclusion from education and other forms. A similar surgical approach should be used on the Bible. Other African scholars who have weighed in on the subject of culture and patriarchy are Ezra Chitando (2004:151) and Lovemore Togarasei (2008:211).

As appraisal, from the review of the CIRCLE writers, they tackle the need for alternative masculinities from the perspective of Christology, mostly by arguing that, unlike traditional Western theology, Jesus suffers and cares. Jesus embodied virtues associated with being a mother of caring, loving and nurturing. Jesus acted differently by opposing the hierarchical oppressive cultural worldview of his time by associating himself with the poor and women. As a critique, I argue that the gender of Jesus as a male Jewish person and narratives where Jesus claims power, authority or imitated the Empire seem to be ignored (Liew 1999:13). This raises the question: are African women dragging the metaphor of Jesus whose gender might be detrimental to their theological reconstruction? In my view, this is not an easy question because on one hand, there are clear narratives where Jesus is the liberator, and most African communities have accepted Jesus as saviour without questioning his gender. However, this is beside the point because this study is not about proper interpretation.

\section{Unintended consequences}

As a brief detour, there are several other writings within the African continent that discuss the issues of alternative masculinities but with what I call 'unintended consequences' by labelling the African men in pejorative symbols. Notably, Mark Hunter (2004:123), who carried out field research in rural areas of KwaZulu Natal in South Africa, argues that the declining number of men in South Africa among the Zulu people is linked to mortality due to risky sexual behaviours. Hunter presents the Zulu men as individuals who risk death to prove their masculinity by having sex with multiple partners. ${ }^{2}$ While the narrative of risky sexual behaviour and death is important, implicitly it drags other stereotypes about black men. What public myths and narratives does Hunter create? A second example is the famous research by Robert Morrell (2007:11) who thinks that masculinities in Africa and South Africa, in particular, are intertwined with politics, gender and culture. Importantly, Morrel suggests that the African worldview gives men the tag of being providers, which given the present hard economic climate most men fail to live up to resulting in men giving up, turning to abuse of alcohol and mistresses. Morrel seems to suggest that alcohol and mistresses function as hideouts from facing the challenges of life.

Arguably, as an unintended consequence, the discussions about gender-based violence intersect with dormant colonial stereotypes to re-ascribe upon black men as hypersexualised - which is laudable in Mark Hunter's discussion. Stuart Hall (1997:224) mentions that, historically, black

2.Surprisingly, Hunter (2004:123) ignores other important plausible variables, for example, that any sexual encounter is likely to produce a girl child, which may explain the reduced number of men. Importantly, he does not mention the hazardous working environments such as mines which reduce the lifespan of men. 
bodies were labelled differently from Western bodies carried and captured in the films, newspapers and anthropological publications, foregrounding the 'other' as different. Differentiating the black male body from the white male counterpart was an important discursive practice to entrench colonial discourse of the ruler and the colonised - these differences were entrenched in symbols and classifications (Douglas 1966:14). In colonial discourses, the black man was discursively represented as violent, brutal towards their own family and short-tempered. This was meant to differentiate them from what was seen as the more civilised Western man. To denigrate the black man as less human and uncouth, focus was put on his emotional instability and his proportionate phallus which was meant to fetishise and objectify him in Western discourses. Stuart Hall (1997) explains that the:

whites often fantasized about the excessive sexual appetite and prowess of the black men, as they did about the lascivious, oversexed character of the black women ... the primal fantasy of the big black penis projects the fear of a threat not only to white womanhood, but to civilisation itself, as the anxiety of miscegenation, eugenic pollution and racial degeneration is acted out through white male rituals aggression - the historical lynching of black men in the United States.... (p. 262)

Arguably Hall's insights provide a critical eye to Mark Hunter's (2004:123) over sexualised Zulu men. Curiously, why is Hunter preoccupied with what he reads as the careless sexual appetites of the Zulu men? Implicitly, to Hunter, the Zulu men seem to irrationally die from unprotected sex merely to prove their masculinity. Implicitly, Hunter resurfaces two dormant stereotypes: firstly, the black man does not think through issues which echo colonial labels of him being a 'boy', meaning lessmatured. Unaware, Hunter seems to present Zulu men as lacking the rational ability to control their sexuality, seemingly portraying them as driven by their sexual desire. Because Zulu men lack rationality and the ability to think through their actions, they lack parenting skills unless tutored and constantly reminded not to be violent to their family and children. From this portrayal, one hears echoes of colonial discourses whereby:

the white male slave master often exercise his authority over black male slave, by depriving him of all the attributes of responsibility, paternal and familial authority, treating him as a child ... symbolically castrating the black man. (Hall 1997:262)

Besides sexual prejudices, in my view, most of the campaign against gender-based violence is done or funded by donor countries who also control the content. These organisations would not dare raise questions related to economic injustices and capitalism because that would infringe on their interests. Plausibly, placing emphasis on gender-based violence tactically diverts attention from questioning structural issues. Arguably, colonial masculinities thrive from diverting blame by presenting it as a social and genetic problem related to black men. Anthony Lemelle Jr (2010:8), in Black masculinities and sexual politics, may be right in saying that alternative masculinities run the risk of further inscribing the black male as violent and lacking parenting skills compared to Western men.

\section{Redirecting the discussion and future studies}

I finish my study by redirecting the discussion about alternative masculinities to issues concerning women's economic empowerment. For the discussions regarding alternative masculinities to gain further impact, I suggest that it should raise the question of economic inequality as the main discursive variable. This is not to assume that the cultural and theological variables are not equally important. Instead, I argue that within a multicultural context dictated by global economy, woman's voices would be better heard if they are economically empowered.

Though I have reservations towards her contribution, Sarojin Nadar (2008:551) made reference to the economy. Using Carol Flinders, who studied pre-agrarian societies, Sarojin Nadar (2008:560) suggests that alternative masculinities should express themselves through 'values of interconnectedness, mutuality and partnership'. In my view the challenge with Nadar's (2008:560) suggestion is that feudal societies were known for being hierarchical, even hunter gatherer or subsistent societies had no values of 'interconnectedness, mutuality and partnership'. In my view, Nadar's (2008:560) suggestion seems to create an imaginary period which never existed in the history of humankind. Furthermore, I find the 'values of interconnectedness, mutuality and partnership' as too subjective; they cannot be measured or enforced.

I argue that, if the economic and structural questions become the main variables to the discussion, then the focus will be on strategies that empower women. I build this perspective on Pierre Bourdieu (1986:241) who argues that a person's social status depends on accumulated social capital. In agreement, Bourdieu's (1986:241) approach is used by liberal feminists in their call for economic empowerment of women. In addition to Bourdieu, I find Peter Hedström and Richard Swedberg (1998:7) useful. They studied dynamics of social power and explained that power in its various forms affects social relations. If $x$ knows that $y$ has higher social capital he or she is likely to approach $y$ with a higher level of respect. The same is true vis-a-vis. In a similar vein if a woman is educated, earns a good salary, her social capital increases and chances of being labelled 'home defender' and/or 'child bearer' are reduced. It is sad that most of the discussions about genderbased violence are targeted towards men to change, yet the reality is that power is not negotiated. For social dynamics to change, as Peter Hedström and Richard Swedberg (1998:7) suggest, the victim should acquire social capital - thus destabilising conduits of social power. Towards this, there are few positive attempts in the form of girl child education and targeted employment of women in strategic sectors of the economy. However, most of such attempts come in the form of charity through non-governmental organisations. 


\section{Conclusion}

The CIRCLE writers made unparalleled contribution to theology and alternative Christology in particular. Concerning alternative masculinities, they call for a Christology that comes from the experiences of African women - of caring, loving and life-oriented. This became the basis to critique the patriarchal imports that present Jesus in exclusively male symbols. These need to be deconstructed. It seems for African women theologians the process of reconstructing an alternative Christology or a reading of the Bible that starts with the experiences of African women is simultaneously the process of crafting alternative masculinities because masculinities hide in patriarchal myths. From this perspective, African women's stories recalibrate Christology and, at the same time, displace masculinities. However, while commending the good work so far, but in view of global capitalism, more effort should be focused towards the economic question because it has the potential to transform spatial arrangements.

\section{Acknowledgements Competing interests}

The author has no financial or personal relationships which may have inappropriately influenced him in writing this article.

\section{References}

Ashe, F., 2007, The politics of masculinity: Men, power and resistance, Routledge, New York.

Bourdieu, P., 1986, 'The forms of capital', in J. Richardson (ed.), Handbook of theory and research for the sociology of education, pp. 241-258, Greenwood, New York.

Carabi, À. \& Armengol, J., 2014, 'Introduction', in À. Carabí \& J.M. Armengol (eds.) Alternative masculinities for a changing world, pp. 1-16, Palgrave MacMillan, New York.

Chitando, E., 2004, “The good wife”: A phenomenological re-reading of proverbs $31: 10-31$ in the context of HIV/AIDS in Zimbabwe', Scriptura: International Journa of Bible, Religion and Theology in Southern Africa 86(2), 151-159.

Connell, R.W. \& Messerschmidt, J., 2005, 'Hegemonic masculinity: Rethinking the concept', Gender and Society 19(6), 829-859. http://dx.doi.org/10.1177 /0891243205278639

Douglas, M., 1966, Purity and danger, Routledge, London.

Dube, Z., 2013, 'Salvation through God's Son: Gendering the Salvation Motif', Journal of Gender and Religion in Africa 19(2), 91-108.

Elliott, M., 2007, 'Human rights and the triumph of the individual in world culture', Cultural Sociology 1(3), 343-363. http://dx.doi.org/10.1177/1749975507082052

Flecha, R., Puigvert, L. \& Ríos, O., 2013, 'The new masculinities and the overcoming of gender violence', International and Multidisciplinary Journal of Social Sciences 2(1), 88-113.
Halberstam, J., 1998, Female Masculinities, Duke University Press, Durham.

Hall, S., 1997, 'The spectacle of the "other"', in S. Hall (ed.), Representations: Cultural representations and signifying practices, pp. 223-290, Open University, London.

Hearn, J. \& Morgan, D. (eds.), 1990, Men, masculinities and social theory, Unwin, London.

Hedström, P. \& Swedberg, R., 1998, 'Social mechanisms: An introductory essay', in P. Hedström \& R. Swedberg (eds.), Social mechanisms: An analytical approach to social theory, pp. 1-31, Cambridge University Press, Cambridge.

Hunter, M., 2004, 'Masculinities and multiple-sexual-partners in KwaZulu-Natal', in G. Reid \& L. Walker (eds.), Men behaving differently in South Africa since 1994, pp. 139-160, Double Storey Books, Cape Town.

Kanyoro, M.A., 2002, Introducing feminist cultural hermeneutics: An African perspective, Sheffield Academic Press, Sheffield.

Kaufman, M. (ed.), 1989, Beyond patriarchy: Essays by men on pleasure, power and Change, Oxford University Press, Toronto.

Kimmel, M.S. (ed.), 1989, Changing men: New directions in research on men and Masculinity, Sage, London.

Lemelle, A.J., Jr., 2010, Black masculinities and sexual politics, Routledge, New York.

Leverenz, D., 2014, 'Aging beyond masculinities, or, the penis as failed synecdoche', in A. Carabí \& J.M. Armengol (eds.), Alternative masculinities for a changing world, pp. 63-98, Palgrave MacMillan, New York.

Liew, B.T., 1999, Politics of the Parousia: Reading mark inter(con) textually, Brill, Leiden.

Marx K., 1887, Capital: A Critique of Political Economy, volume 1, Translated by Samuel Moore and Edward Aveling, Progress Publisher, Moscow.

Masenya, (ngwan'a Mphahlele), M., 2015, 'An African methodology for South African biblical science: Revisiting the Bosadi (Womanhood) approach', in M.J. Smith (ed.), I found God in me: A womanist biblical hermeneutics reader, n.p., Oregon, Cascade.

Millet, K., 1971, Sexual politics, University of Illinois Press, Chicago, IL.

Morrell, R., 2007, 'Men, masculinities and gender politics in South Africa: A reply to Macleod', Pins 35, 15-26.

Mutua, A., 2006, 'Introduction: Mapping contours of progressive Masculinities', in A. Mutua (ed.), Progressive black masculinities, pp. xi-1, Routledge, New York.

Nadar, S., 2008, 'Palatable patriarchy and violence against wo/men in South Africa: Angus Buchan's mighty men's conference as a case study of masculinism', Scriptura 102(2009), 551-561. http://dx.doi.org/10.7833/102-0-614

Oduyoye, M.A., 1988, 'The Christ for African women', in V. Fabella \& M.A. Oduyoye (eds.), With passion and compassion: Third world women doing theology. Reflections from the Women's Commission of the Ecumenical Association of Third World Theologians, pp. 35-46, Orbis, Maryknoll, NY.

Oduyoye, M.A., 2001, Introducing African Women's theology, Sheffield Academic Press, Sheffield.

Okure, T., 2000, 'First was life, not the book', in T. Okure (ed.), To cast fire upon the Earth: Bible and mission collaborating in today's multicultural gobal context, pp. 194-214, Cluster, Natal.

Pease, B., 2014, 'Reconstructing masculinity or ending manhood? The potential and limitations of transforming masculine subjectivities for gender equality', in À. Carabí \& J.M. Armengol (eds.), Alternative masculinities for a changing world, pp. 17-34, Palgrave MacMillan, New York.

Phiri, I., 2007, Women, Presbyterianism and patriarchy; Religious experiences of Chewa women in central Malawi, Kachere Series, Zomba.

Stanton, E.C., 1993, The women's Bible: So God created man in his image, I the image of God created he him, male and female created he them, Northeastern University, Boston, MA.

Togarasei, L., 2008, 'Fighting HIV and AIDS with the Bible: Towards HIV and AIDS biblical criticism', in E. Chitando (ed.), Mainstreaming HIV in theology and religious studies: Experiences and explorations, pp. 211-222, WCC, Geneva.

Van Klinken, A., 2013, Transforming masculinities in African Christianity: Gender controversies in times of AIDS, Routledge, London.

Vilarrubias, M.B., 2014, Transitory masculinities in Post-9/11 Arab American literature written by women', in À. Carabí \& J.M. Armengol (eds.), Alternative masculinities for a changing world, pp. 205-218, Palgrave MacMillan, New York. 